\title{
Corrected QT Interval
}

National Cancer Institute

\section{Source}

National Cancer Institute. Corrected QT Interval. NCI Thesaurus. Code C100391.

The time interval between the start of the $\mathrm{Q}$ wave and the end of the $\mathrm{T}$ wave in the cardiac cycle as corrected with a non-specified correction formula. 